\title{
RESEARCH ON QUALITY OF MAIZE GRAIN AS A RESULT OF THE APPLICATION OF AN INNNOVATIVE SYSTEM FOR STORING GRAIN UNDER OPERATING CONDITIONS
}

\author{
Anna Bartkowiak ${ }^{\mathrm{a}}$, Weronika Gracz ${ }^{\mathrm{a}}$, Damian Marcinkowski ${ }^{\mathrm{a}}$, Damian Skrzypek ${ }^{\mathrm{b}}$, \\ Szymon Wojtaszyk ${ }^{\mathrm{b}}$ \\ a Institute of Technology and Life Sciences, Falenty, Hrabska 3, 05-090 Raszyn \\ b Polnet, Sowia 13B, 62-080 Tarnowo Podgórne
}

Anna Bartkowiak; ORCID 0000-0002-3778-7869; Weronika Gracz; ORCID 0000-0003-3769-5515 Damian Marcinkowski; ORCID 0000-0002-9488-3603; Damian Skrzypek; ORCID 0000-0001-7920-648X; Szymon Wojtaszyk; ORCID 0000-0001-6868-5219

* Corresponding author: e-mail: d.marcinkowski@itp.edu.pl

\begin{tabular}{|c|c|}
\hline ARTICLE INFO & ABSTRACT \\
\hline $\begin{array}{l}\text { Article history: } \\
\text { Received: July } 2019 \\
\text { Received in the revised form: } \\
\text { August } 2019 \\
\text { Accepted: September } 2019\end{array}$ & \multirow{2}{*}{$\begin{array}{l}\text { This study analyses the results of research on the improvement of grain } \\
\text { quality using a filling core in a grain silo. The research is a part of the } \\
\text { research project aimed at developing an innovative system for drying } \\
\text { and storing maize grain that, among other benefits, reduces grain dam- } \\
\text { age. Two series were carried out: a control series, in which a chute was } \\
\text { applied as the main element, and an operation series, in which a cascade } \\
\text { chute was used for testing. The analysis conducted on the simulated } \\
\text { operating conditions showed a 4-5-fold reduction in the amount of grain } \\
\text { damaged following the application of the filling core compared with the } \\
\text { control series. It has also been shown that a 6-meter cascade chute con- } \\
\text { siderably decreases the velocity of the falling grain when loading the } \\
\text { silo. }\end{array}$} \\
\hline $\begin{array}{l}\text { Key words: } \\
\text { maize grain, } \\
\text { filling core in grain silo, } \\
\text { grain quality }\end{array}$ & \\
\hline
\end{tabular}

\section{Introduction}

Maize is one of the basic cereals. Its global economic significance is growing year by year as evidenced by its higher share in the sown area. The main characteristics of this plant are its high yields and various nutritional purposes (Evenson and Gollin, 2015; Herrmann and Rath, 2012; Shiferaw et al., 2013; Zhu, 2018). According to FAOSTAT (2018), the world's largest maize production, almost 53\%, is recorded in America, which is followed by Asia (28.5\%), Europe (11.4\%), and Africa (7.1\%). In Poland, maize is also becoming increasingly important. There, the first sowings of this cereal were recorded in the 1950s; however, at that time the structure of sowings did not exceed $0.04 \%$ in comparison with the total area of sown cereals. Moreover, until the 1990 s maize was used mainly as green fodder. The breakthrough occurred after 2000. In 2005, maize acreage in the total area of sown cereals amounted to almost 5.2\%, while in 2007 it was 7.4\% (Polish Central Statistical Office, 2005, 2018). 
Although maize is highly popular, technical and technological solutions for drying and storing grain continue to be sought. Those processes require relatively large financial outlays. Bernardes et al. proved that the cost of drying grain may be as much as $30 \%$ of its total cost (Bernardes et al., 2018). Postharvest losses of maize during storage remain a significant challenge for many farmers (Abass et al., 2014; Bbosa et al., 2017; Giorni et al., 2008; Suleiman et al., 2018; Walker et al., 2018).

In addition to cost, a significant element is the quality of the grain. In practical terms, immediately upon harvesting but before storing maize, it is necessary to completely dry it out as its moisture is 2-3 times higher compared to other cereals. The storage of wet maize results in its decay and, consequently, in the loss of its economic value (Bassu et al., 2014; Carvalho et al., 2017). It is assumed that maize should be dried in air at a temperature of approximately $100^{\circ} \mathrm{C}$, while rape or wheat, for example, are dried at around $50^{\circ} \mathrm{C}$. During its storage in the silo, maize is crushed as a result of falling from a great height. Maize grains are extremely brittle due to the absence of gluten, which is a natural internal binder of the grain. Various mechanical, physical, and biological factors that can cause damage are involved in all activities related to grain extraction, cleaning, transport and storage. A grain may be damaged to varying degrees, from single cracks that do not break the grain shield structure, to halving, splitting into smaller pieces, and crushing. In addition, depending on the quality of the harvest and the effectiveness of the cleaning process, grain portions can include various types of contamination that may adversely affect further grain management (Liu et al., 2012; Meyers and Hollinger, 2004).

Furthermore, in the silo maize is divided into fractions of solid grain and crushed grain, causing the grain layers to move and leading to asymmetrical pressure on the silo walls. The silos are then much more heavily loaded, which requires additional reinforcement of their structure. The asymmetrical loading of silo walls decreases their durability and increases costs related to their use (Scaar et al., 2015; Tonui et al., 2014; Weigler et al., 2012).

Therefore, the objective of the study was to apply a solution - a component of the system of drying and storing maize grains that significantly reduces grain damage. The specific objective was to conduct research on the improvement of grain quality using the filling core in the grain silo under simulated operating conditions.

\section{Research methodology}

The research was conducted at the Polnet and at the Institute of Technology and Life Sciences, Poznań Branch. It was based on feed maize grains that were used to carry out the laboratory analysis, i.e., to determine the total proportion of damaged grains to solid grains in the research material delivered.

Considering the method of cereal-grain quality assessment in accordance with the Commission Regulation (EU) No 1272/2009 of 11 December 2009 relating to buying-in and sale of agricultural products under public intervention ("Regulation"), maize is assessed using the fractionation method and sieves with a $4.5 \mathrm{~mm}$ round mesh and spaced at a distance of 1.8 $\mathrm{mm}$. The Regulation defines damaged grains as grains unusable for livestock feed due to putrefaction, mildew, bacteria, or other causes. 
Research on quality...

Considering the aforesaid method, the fractions of maize grain are defined as follows:

- broken grain means a fraction of fine grain and pieces of crushed grain with a lump size that enables it to pass through apertures of the sieve; the fraction of grain under the sieve.

- solid grain means a fraction of grain that is undamaged or damaged in a way that prevents it from passing through the sieve; the fraction of grain above the sieve.

In this study, due to the empirical use of material, the class of solid grains is additionally classified into undamaged and damaged grains.

The grain fraction was evaluated using 5 consecutive portions of 1,000 g grain collected from inside the bulk cone by means of a manual probe under I-ZPE/107. Having been put through the sieve to separate broken grains, the remaining portion of grain left in the sieve was manually separated into two classes: solid grains and damaged grains.

The main objective of the research was to determine the extent to which the use of the central column with a cascade chute to fill the silo with grain mitigates mechanical damage to maize. In order to carry out an empirical inference, two series of assessments of the degree of grain damage with a free fall from a height of 3 meters and 6 meters were performed: the control series, in which a portion of grain was freely dropped onto concrete and steel surfaces, was a reference point for the operation series. This provided a picture of grain damage when filling up silos without devices that prevent them from being damaged. Subsequently, the operation series was tested, i.e., a portion of maize was dropped from the same height onto the same surfaces using a column with the cascade chute.

The comparison of the weight of fractions of damaged maize grains in both series was a measure of the effect of the use of a column with the cascade chute for silo filling on the grain damage level.

\section{Control series}

In order to drop maize grains from the required height $(3 \mathrm{~m}$ and $6 \mathrm{~m})$, a test stand was constructed. The main component of the equipment was a chute (Figure 1) made of a pipe with an external diameter of $160 \mathrm{~mm}$, mounted on a laboratory crane. In the opening of the chute, a manual gate was installed to fill and immediately empty the chute hopper. Under the gate valve, a section of a pipe was placed to stabilize the direction of the stream of falling grain after opening the gate valve. The volume of the hopper over the gate valve was $9 \mathrm{dcm}^{3}$, which, with the bulk density of maize grain estimated at $742 \mathrm{~kg} \cdot \mathrm{m}^{-3}$, enabled a one-off drop of $5 \mathrm{~kg}$ of maize grain. The grain was dropped onto a high wall tray with dimensions of $1 \times 1 \times 0.2 \mathrm{~m}$ and made of 2-mm-thick stainless steel. The 3- and 6-meter-high drops were calculated from the level of the gate valve in the chute to the level of the tray bottom and measured with a laser pointer (ZPE-U-37) with an accuracy of $\pm 0.05 \mathrm{~m}$.

In order to avoid the loss of grain after the drop due to splashes caused by rebounds, a cloth cover was kept in place above the tray to direct the rebounded grains onto the tray.

To assess the mechanical damage to the grain dropped from a certain height that simulated the fall of the grain when loading the silo, 20 portions of $1000 \mathrm{~g}$ maize grains were prepared that were collected randomly in accordance with I-ZPE/107 using a manual probe from the inside of the bulk cone, including 10 portions of unbroken grains taken from over the sieve and 10 portions of solid and undamaged grain selected manually. Maize grain used in our research has a moisture content of $18 \%$. 

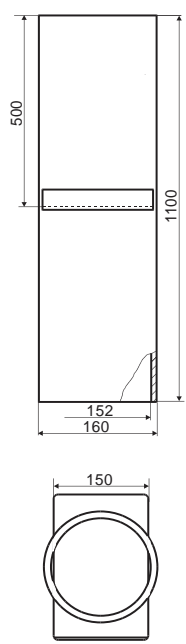

Figure 1. Diagram of a device for dropping grains equipped with a manual gate valve and mounted on a test stand for evaluating the crushing of maize grains during the free loading of the silo (top picture - longitudinal section; bottom picture - cross-section with gate valve).

After each sample drop, the sample was collected from the tray. Subsequently, solid and damaged grains were sieved manually, and, finally, individual fractions were weighed. The obtained weight of damaged grains was a measure of grain damage caused by falling from a certain height.

\section{Fall of unbroken grain samples}

The $1,000 \mathrm{~g}$ samples of grain that were left on the sieve with a mesh diameter of $4.5 \mathrm{~mm}$ during the sieving process were dropped using the device for dropping grains fixed to the laboratory crane. The height from the gate valve of the chute, and thus the drop height, was $3 \mathrm{~m} \pm 0.05 \mathrm{~m}$, and then $6 \mathrm{~m} \pm 0.05 \mathrm{~m}$ above the level of the bottom of the tray onto which the grain was dropped. Under the same conditions, two other experiments were conducted in which samples of manually selected solid and undamaged maize grains were dropped. After dropping each sample, grain fractions were manually selected once again. The remaining mechanically damaged grains were put through the sieve to determine the proportion of broken grains. In these experiments, a measure of grain damage was the weight of grains mechanically damaged during the fall in relation to the weight of undamaged grain.

\section{Operation series}

The reduction of grain damage caused by the fall from the silo with the cascade chute was determined in tests in which maize grains were dropped from the required height ( $3 \mathrm{~m}$ and 6 $\mathrm{m})$. A test stand, the key component of which was a 6.1-m-high cascade chute made of gal- 
Research on quality...

vanized sheet metal and fixed inside the steel grid, was constructed. The cascade chute comprised 15 working components (C-bars) with dimensions of 420x360x20, on the bottom of which the grain slides down in a counter-rotating manner. The cascade consisted of C-bars arranged alternately at an angle of $38 \div 39^{\circ}$ to the ground level. Its individual planes are spaced out in relation to each other with a gap of approximately $75 \mathrm{~mm}$ in height. Each plane of the C-bar on which the grain slides down ends approximately $100 \mathrm{~mm}$ from the vertical part of the next inclined plane; here, the sliding grain changes its direction. The theoretical length of the path covered by the grain in this cascade chute that transports the grain vertically for a distance of about $6 \mathrm{~m}$ is approximately $8.1 \mathrm{~m}$.

For charging the chute, a $4.5 \mathrm{dcm}^{3}$ hopper tank was used, which, with a bulk density of maize grain rated above $742 \mathrm{~kg} \cdot \mathrm{m}^{-3}$, allows a single drop of $2.5 \mathrm{~kg}$ of maize grain. The discharge was made into a high-walled cuvette with dimensions of $1 \times 1 \times 0.2 \mathrm{~m}$ and made of 2-mm-thick stainless steel. The height of the discharge of 6.1 meters was counted from the level of the upper edge of the cascade to the level of the bottom of the cuvette and measured with a laser rangefinder (ZPE-U-37) with an accuracy of $\pm 0.05 \mathrm{~m}$. In order to avoid grain losses after the discharge as a result of the spray resulting from the reflections, a fabric cover was kept in place over the cuvette and used to return the reflected grains to the inside of the cuvette.

\section{Investigation of grain damage discharged by the core - a cascade of chute}

To assess the mechanical damage to the grain after cascade core discharge, which was subject to operational evaluation under industrial conditions, 20 portions of $1000 \mathrm{~g}$ of maize grains were taken at random in accordance with I-ZPE / 107 using a hand sampler from the inside of the cone, with 10 portions being uncrushed grain from the sieves; the remaining 10 portions were all undamaged grains selected by hand. Each time a sample was taken, the sample was carefully collected from the cuvette. Then, the sieves were sieved and the whole and damaged grains were manually selected, and the individual fractions weighed at the end. The obtained mass of damaged grains was a measure of grain damage after discharge from a given height.

\section{Dropping unbroken grain}

Samples weighing $1000 \mathrm{~g}$ from grain remaining during sieving on a sieve with $4.5 \mathrm{~mm}$ diameter holes were dropped using a cascade core attached to a laboratory crane.

\section{Drop of whole grain}

Under the same conditions, another batch cascade experience was conducted with samples consisting of hand-selected whole, intact maize grains. After the sample was removed, the grain fractions were manually reselected. The remaining mechanically damaged grains 
A. Bartkowiak, W. Gracz, D. Marcinkowski, D. Skrzypek, S. Wojtaszyk

were screened through a sieve to determine what parts of the grains were broken. The measure of grain damage in this experiment was the mass of mechanically damaged grains during discharge by means of a charging cascade.

\section{Study of corn sagging on the feed cascade of the silo filling}

The aim of the study was to determine the extent to which the speed of grain dropping during silo-loading with the use of the core in the form of a charging cascade would decrease.

The control series, which is the reference result, was the speed obtained by a portion of grain dropped freely on a test stand equipped with a grain-shedding device. The exploitation series was made on a test bench equipped with a charging cascade with a total height of $6.1 \mathrm{~m}$. Grain drop time during free discharge on a grain-dropping device was evaluated for samples of $1000 \mathrm{~g}$ of maize grain with a calibrated stopper (ZPE-U-28).

In order to check the speed of grain movement after the charging cascade, while filling the grain, a specific amount of corn stained with red ink was added to its stream, and the amount of time it took the stained grain to appear at the outlet of the cascade was measured. In addition, attempts were made to slide the grain sample with a mass of $1000 \mathrm{~g}$, and the amount of time it took for the sample to reach the edge of the last cascade plane and the level of the high-walled cuvette on which the charging cascade was set was measured.

The obtained research results were compiled in the form of a tabular summary. Each of our tests was repeated 10 times, the arithmetic mean, and measurement uncertainty were determined.

\section{Research results}

The size and type of maize grain fraction after sieving and manually sorting a 1,000 $\mathrm{g}$ sample is shown in Table 1 and illustrated in Image 1.

Table 1.

Values of fraction weight after sieving maize grains $(g)$

\begin{tabular}{lcccc}
\hline \multirow{2}{*}{ No. } & Sample weight & \multicolumn{2}{c}{$\begin{array}{c}\text { Grains are all } \\
\text { over the sieve }\end{array}$} & $\begin{array}{c}\text { Grains broken } \\
\text { under the sieve }\end{array}$ \\
\cline { 3 - 5 } & & Unbroken & Broken & Broken \\
\hline 1 & 1000 & 835.45 & 97.05 & 77.95 \\
2 & 1000 & 858.85 & 82.49 & 58.66 \\
3 & 1000 & 834.96 & 94.08 & 70.96 \\
4 & 1000 & 864.47 & 81.26 & 54.39 \\
5 & 1000 & 840.79 & 81.58 & 64.70 \\
Average & 1000 & 846.90 & 87.29 & 65.33 \\
\hline
\end{tabular}


Research on quality...

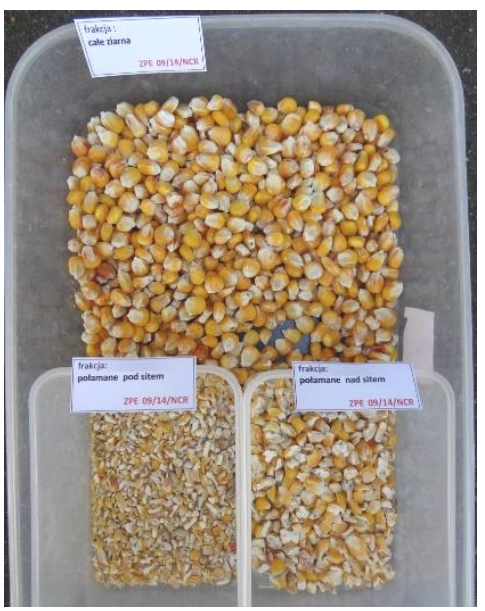

Image 1. General view of the grain fraction after sowing $1 \mathrm{~kg}$ of a maize grain sample.

In order to fill silos used for drying and storing grains, it was necessary to elevate the portion of grain to a certain height determined by the height of the silo chute, and then to drop it from that height to the level of the previously dropped grain. It was shown that the first portion of grain fell to the lowest level of the silo and was mechanically damaged due to the fall onto the surface of the material of which the silo bottom was made.

Preliminary tests conducted during the fall of grain from the height of $3 \mathrm{~m}$ onto the concrete and then onto the steel surface (the tray) did not show any statistically significant differences in the quantity of damaged grain. Therefore, in further tests a steel tray was employed to collect the dropped solid grain in a more accurate way.

The results of 20 drops are shown in Tables 2 and 3.

Table 2 .

Results of evaluation of the weight of maize grain fractions after a free fall of unbroken grain samples from a height of $3 \mathrm{~m}(\mathrm{~g})$

\begin{tabular}{lccc}
\hline \multirow{2}{*}{ No. } & $\begin{array}{c}\text { Before dropping } \\
\text { mass over the sieve }\end{array}$ & \multicolumn{2}{c}{ After dropping } \\
\cline { 3 - 4 } 1 & 1000.0 & 996.35 & 3.50 \\
2 & 1000.0 & 995.38 & 4.41 \\
3 & 1000.0 & 992.74 & 7.04 \\
4 & 1000.0 & 991.89 & 8.00 \\
5 & 1000.0 & 995.18 & 4.62 \\
6 & 1000.0 & 994.29 & 5.54 \\
7 & 1000.0 & 995.80 & 4.12 \\
8 & 1000.0 & 996.17 & 3.74 \\
9 & 1000.0 & 993.87 & 6.05 \\
10 & 1000.0 & 995.59 & 4.11 \\
Average & 1000.0 & 994.73 & 5.11 \\
\hline
\end{tabular}


A. Bartkowiak, W. Gracz, D. Marcinkowski, D. Skrzypek, S. Wojtaszyk

The degree of damage to unbroken grains after a free fall of a 1,000 $\mathrm{g}$ sample from a height of $3 \mathrm{~m}$ in 10 repetitions (Table 2) was, on average, $5.11 \pm 0.95 \mathrm{~g}$, but the expanded uncertainty was calculated for by the confidence level of $95 \%$ and the extension factor $\mathrm{k}=2$. This represented $0.5 \pm 0.1 \%$ of the size of the dropped sample.

Table 3.

Results of evaluation of the weight of maize grain fractions after a free fall of unbroken grain samples from a height of $6 \mathrm{~m}(\mathrm{~g})$

\begin{tabular}{lccc}
\hline \multirow{2}{*}{ No. } & Before dropping & \multicolumn{2}{c}{ After dropping } \\
\cline { 2 - 4 } mass over the sieve & mass over the sieve & mass under the sieve \\
\hline 1 & 1000.0 & 982.39 & 17.50 \\
2 & 1000.0 & 983.05 & 16.81 \\
3 & 1000.0 & 981.69 & 18.14 \\
4 & 1000.0 & 980.46 & 19.40 \\
5 & 1000.0 & 978.03 & 21.83 \\
6 & 1000.0 & 980.10 & 19.82 \\
7 & 1000.0 & 981.16 & 18.79 \\
8 & 1000.0 & 977.84 & 22.05 \\
9 & 1000.0 & 981.39 & 18.44 \\
10 & 1000.0 & 982.52 & 17.28 \\
Average & 1000.0 & 980.86 & 19.01 \\
\hline
\end{tabular}

The degree of damage to unbroken grains after a free fall of a 1,000 g sample from a height of $6 \mathrm{~m}$ in 10 repetitions (Table 3) was, on average, $19.01 \pm 1.14 \mathrm{~g}$, but the expanded uncertainty was calculated for by the confidence level of $95 \%$ and the extension factor $\mathrm{k}=2$. This represented $1.9 \pm 0.1 \%$ of the size of the dropped sample.

The results of the fall of solid grain from the height of $3 \mathrm{~m}$ and then from the height of 6 $\mathrm{m} \pm 0.05 \mathrm{~m}$ are shown in Tables 4 and 5 .

Table 4.

Results of evaluation of the weight of maize grain fractions after a free fall of selected solid grain samples from the height of $3 \mathrm{~m}(\mathrm{~g})$

\begin{tabular}{lccccc}
\hline No. & $\begin{array}{c}\text { Before } \\
\text { dropping } \\
\text { mass over the } \\
\text { sieve }\end{array}$ & $\begin{array}{c}\text { Mass of whole } \\
\text { grains }\end{array}$ & $\begin{array}{c}\text { After dropping } \\
\text { broken } \\
\text { Mass over } \\
\text { the sieve }\end{array}$ & $\begin{array}{c}\text { Broken } \\
\text { mass under } \\
\text { the sieve }\end{array}$ & $\begin{array}{c}\text { Total weight of } \\
\text { damaged grains }\end{array}$ \\
\hline 1 & 1000.0 & 990.39 & 8.78 & 0.78 & 9.57 \\
2 & 1000.0 & 992.94 & 6.65 & 0.35 & 7.02 \\
3 & 1000.0 & 989.50 & 9.88 & 0.55 & 10.55 \\
4 & 1000.0 & 991.90 & 7.50 & 0.40 & 7.92 \\
5 & 1000.0 & 990.81 & 8.31 & 0.81 & 9.15 \\
6 & 1000.0 & 988.26 & 10.66 & 1.02 & 11.71 \\
7 & 1000.0 & 990.41 & 8.74 & 0.79 & 9.56 \\
8 & 1000.0 & 989.92 & 9.31 & 0.72 & 10.05 \\
9 & 1000.0 & 991.21 & 8.20 & 0.46 & 8.68 \\
Average & 1000.0 & 989.85 & 9.28 & 0.40 & 9.74 \\
\hline
\end{tabular}


Research on quality...

The degree of damage to manually selected solid grains after a free fall of a 1,000 g sample from a height of $3 \mathrm{~m}$ in 10 repetitions (Table 4) was, on average, $9.39 \pm 0.83 \mathrm{~g}$, but the expanded uncertainty was calculated for by the confidence level of $95 \%$ and the extension factor $\mathrm{k}=2$. This represented $1.0 \pm 0.1 \%$ of the size of the dropped sample.

Table 5.

Results of evaluation of the weight of maize grain fractions after a free fall of selected solid grain samples from the height of $6 \mathrm{~m}(\mathrm{~g})$

\begin{tabular}{|c|c|c|c|c|c|}
\hline \multirow[b]{2}{*}{ No. } & \multirow{2}{*}{$\begin{array}{c}\text { Before } \\
\text { dropping } \\
\text { Mass of whole } \\
\text { grains }\end{array}$} & \multicolumn{3}{|c|}{ After dropping } & \multirow[b]{2}{*}{$\begin{array}{c}\text { Total weight } \\
\text { of damaged grains }\end{array}$} \\
\hline & & $\begin{array}{l}\text { Mass of whole } \\
\text { grains }\end{array}$ & $\begin{array}{l}\text { Damaged } \\
\text { mass over } \\
\text { the sieve }\end{array}$ & $\begin{array}{l}\text { Broken } \\
\text { mass under } \\
\text { the sieve }\end{array}$ & \\
\hline 1 & 1000.0 & 952.07 & 40.56 & 6.74 & 47.26 \\
\hline 2 & 1000.0 & 954.66 & 36.89 & 7.55 & 44.44 \\
\hline 3 & 1000.0 & 948.58 & 45.70 & 5.52 & 51.20 \\
\hline 4 & 1000.0 & 958.90 & 35.35 & 5.65 & 41.03 \\
\hline 5 & 1000.0 & 953.50 & 42.67 & 3.72 & 46.44 \\
\hline 6 & 1000.0 & 950.18 & 45.39 & 4.10 & 49.50 \\
\hline 7 & 1000.0 & 961.26 & 34.67 & 3.77 & 38.45 \\
\hline 8 & 1000.0 & 945.61 & 49.48 & 4.65 & 54.15 \\
\hline 9 & 1000.0 & 953.04 & 42.88 & 3.94 & 46.87 \\
\hline 10 & 1000.0 & 947.20 & 48.65 & 4.12 & 52.79 \\
\hline Average & 1000.0 & 952.50 & 42.22 & 4.98 & 47.21 \\
\hline
\end{tabular}

The degree of damage to manually selected solid grains after a free fall of a 1,000 g sample from the height of $6 \mathrm{~m}$ in 10 repetitions (Table 5) was, on average, $47.20 \pm 3.15 \mathrm{~g}$, but the expanded uncertainty was calculated for by the confidence level of $95 \%$ and the extension factor $\mathrm{k}=2$. This represented $4.79 \pm 0.1 \%$ of the size of the dropped sample. The share of the fraction of damaged grains under the sieve in samples after the 6-metre fall was, on average, $4.98 \pm 0.85 \mathrm{~g}$. Table 6 shows the results of the average weight of fractions of damaged maize grains for the tested types of samples (selected solid and undamaged grains) dropped freely from the height of 3 and 6 metres.

Table 6.

Average results of evaluation of the weight of maize grain fraction damaged after a free fall from heights of 3 and $6 \mathrm{~m}$.

\begin{tabular}{lccc}
\hline & \multicolumn{3}{c}{ Sample type } \\
\cline { 2 - 4 } $\begin{array}{l}\text { Discharge } \\
\text { height }\end{array}$ & \multicolumn{3}{c}{ Whole grains } \\
& $\begin{array}{c}\text { Grains damaged after the } \\
\text { discharge }\end{array}$ & $\begin{array}{c}\text { Grains broken * (under } \\
\text { sieve) }\end{array}$ & $\begin{array}{c}\text { Grains undamaged } \\
\text { Grains broken (under } \\
\text { sieve) after discharge } \\
(\mathrm{m})\end{array}$ \\
\hline 3 & 9.39 & 0.63 & $(\mathrm{~g})$ \\
6 & 47.21 & 4.98 & 5.11 \\
\hline * component of mechanically damaged grains after discharge & & 19.01 \\
\hline
\end{tabular}


A. Bartkowiak, W. Gracz, D. Marcinkowski, D. Skrzypek, S. Wojtaszyk

Finally, the results of research on the control series of the free fall of maize grain used as a test material shown in Table 6 prove that the 6-metre height of the cascade chute is sufficient to determine whether the design of the falling core used to load grain silos reduces damage to the grain transported by the cascade. The results obtained during 10 drops are shown in Table 7.

Table 7.

Results of evaluation of the weight of maize grain fractions after a fall of unbroken grain samples through the cascade chute from the height of $6.1 \mathrm{~m}(\mathrm{~g})$

\begin{tabular}{|c|c|c|c|c|}
\hline \multirow[b]{2}{*}{ No. } & \multirow{2}{*}{$\begin{array}{l}\text { Before dropping } \\
\text { mass over } \\
\text { the sieve }\end{array}$} & \multicolumn{2}{|c|}{ After dropping } & \multirow[b]{2}{*}{ Loss } \\
\hline & & $\begin{array}{c}\text { Mass over } \\
\text { the sieve }\end{array}$ & $\begin{array}{c}\text { Mass under } \\
\text { the sieve }\end{array}$ & \\
\hline 1 & 1000.0 & 995.66 & 2.84 & 1.50 \\
\hline 2 & 1000.0 & 993.82 & 4.63 & 1.55 \\
\hline $3 *$ & $1000.0 *$ & $986.48 *$ & $3.68 *$ & $9.84 *$ \\
\hline 4 & 1000.0 & 991.61 & 5.37 & 3.02 \\
\hline 5 & 1000.0 & 995.69 & 4.11 & 1.20 \\
\hline 6 & 1000.0 & 990.52 & 6.87 & 2.93 \\
\hline 7 & 1000.0 & 992.08 & 5.66 & 2.26 \\
\hline 8 & 1000.0 & 991.21 & 5.94 & 2.85 \\
\hline 9 & 1000.0 & 994.36 & 4.26 & 1.38 \\
\hline 10 & 1000.0 & 992.86 & 5.75 & 1.39 \\
\hline 11 & 1000.0 & 993.67 & 4.85 & 1.48 \\
\hline Average* $^{*}$ & 1000.0 & 993.15 & 5.03 & 1.96 \\
\hline
\end{tabular}

During the fall by means of the cascade core, losses of grain caused by rebounds on the upper floors of the cascade were observed, causing the grain to escape from the test stand. For sample No. 3, as a result of Dixon's Q test conducted to statistically estimate an error rate, the loss of $3.02 \mathrm{~g}$ was considered an error in the sample group $\mathrm{n}=10$, and the measurement was rejected $-\mathrm{Qn}=0.789>\mathrm{Qkr}=0.437$ (where $d f=9, \alpha=0.05$ ). Another test was carried out, and the result is shown in item 11 of Table 7. Dixon's Q test did not show any errors for 10 supplemented measurements.

The degree of damage to unbroken grains after dropping a 1,000 g sample through the cascade chute from the height of $6.1 \mathrm{~m}$ in 10 repetitions (Table 7) was, on average, $5.03 \pm$ $0.72 \mathrm{~g}$, but the expanded uncertainty was calculated for by the confidence level of $95 \%$ and the extension factor $\mathrm{k}=2$. This represented $0.5 \%$ of the size of the dropped sample.

In comparison with the control series in adequate conditions, the average of $19.01 \pm 1.14$ $\mathrm{g}$ of damaged grains (Table 3) was obtained for unbroken grains after a free fall, and after using the cascade chute, the degree of damage to grain was 4 times lower. It was assumed that the amount of approximately $1.5 \mathrm{~g}$ of the grain that fell alongside was not damaged.

The results of the fall of solid grain from the height of $6.1 \mathrm{~m} \pm 0.05 \mathrm{~m}$ by means of the cascade chute are included in Table 8. 
Research on quality...

Table 8

Results of evaluation of the weight of maize grain fractions after a free fall of selected solid grain samples through the cascade chute from the height of $6.1 \mathrm{~m}(\mathrm{~g})$

\begin{tabular}{|c|c|c|c|c|c|}
\hline \multirow[b]{2}{*}{ No. } & \multirow{2}{*}{$\begin{array}{l}\text { Before dropping } \\
\text { Mass of whole } \\
\text { grains }\end{array}$} & \multicolumn{4}{|c|}{ After dropping } \\
\hline & & $\begin{array}{c}\text { Mass of whole } \\
\text { grains }\end{array}$ & $\begin{array}{c}\text { damaged } \\
\text { mass over } \\
\text { the sieve }\end{array}$ & $\begin{array}{c}\text { broken } \\
\text { mass under } \\
\text { the sieve }\end{array}$ & $\begin{array}{l}\text { Total weight of } \\
\text { damaged grains }\end{array}$ \\
\hline 1 & 1000.0 & 991.34 & 7.45 & 0.24 & 7.71 \\
\hline 2 & 1000.0 & 987.26 & 11.50 & 0.51 & 12.02 \\
\hline 3 & 1000.0 & 985.02 & 12.27 & 0.34 & 12.62 \\
\hline 4 & 1000.0 & 987.04 & 11.29 & 0.18 & 11.48 \\
\hline 5 & 1000.0 & 989.26 & 9.78 & 0.18 & 9.97 \\
\hline 6 & 1000.0 & 990.05 & 7.83 & 0.28 & 8.12 \\
\hline 7 & 1000.0 & 990.99 & 7.02 & 0.20 & 7.29 \\
\hline 8 & 1000.0 & 993.17 & 5.44 & 0.21 & 5.70 \\
\hline 9 & 1000.0 & 992.33 & 6.34 & 0.20 & 6.53 \\
\hline 10 & 1000.0 & 991.63 & 7.13 & 0.29 & 7.42 \\
\hline Average & 1000.0 & 989.81 & 8.61 & 0.26 & 8.89 \\
\hline
\end{tabular}

The average weight of mechanically damaged grains in $1000 \mathrm{~g}$ samples of the selected solid maize grains falling through the cascade chute from the height of $6.1 \pm 0.05 \mathrm{~m}$ was equal to $8.89 \pm 1.55 \mathrm{~g}$. The expanded uncertainty was calculated for by the confidence level of $95 \%$ and the extension factor $\mathrm{k}=2$. This corresponds to approximately $1 \%$ of the mechanical damage to the dropped grains.

In comparison to the control series in adequate conditions, for the selected solid grain after a free fall, the average of $47.2 \pm 3.15 \mathrm{~g}$ of the damaged grains was obtained (Table 7), and after the use of the cascade chute, the damage to grains was reduced by more than 5 times $(8.9 \pm 1.55 \mathrm{~g})($ Table 8$)$.

In addition, Table 8 displays the results of the weight of the broken grain fraction after the fall of samples of the selected solid grains through the cascade chute. The average weight of broken grains amounted to $0.26 \pm 0.03 \mathrm{~g}$. This is much less damage compared to the direct fall from this height, where the damage was about $5 \mathrm{~g}$.

As shown in Table 9, the velocity of the free fall of a $1000 \mathrm{~g}$ grain sample in the device used to drop grains was so high that an error of the operator of the manual gate valve at a height of $6 \mathrm{~m}$ and an error of the operator of the stopper made it impossible to obtain the correct measurement for the falling time of the grain.

The average time for grain sliding down the cascade chute calculated by measuring the time when coloured grains appeared in the grain stream at the end of the cascade (the first 10 samples in Table 9) was $3.73 \pm 0.06 \mathrm{sec}$. The average time for a $1000 \mathrm{~g}$ grain sample sliding down the cascade chute, calculated by measuring the time when the sample rolls off the edge of the last plane of the cascade and the tray on which the cascade chute is placed (tests 11-15 in Table 9), was $3.69 \pm 0.14 \mathrm{sec}$. This proves that the times for grain sliding down the cascade chute measured by two methods are similar and the differences are not statistically significant. 
A. Bartkowiak, W. Gracz, D. Marcinkowski, D. Skrzypek, S. Wojtaszyk

Table 9.

Free-fall time and time for sliding down the cascade chute in a maize-grain sample test

\begin{tabular}{ccc}
\hline No. & Free-fall time (s) & Comments \\
\hline 1 & immeasurable & stream, grain unbroken \\
2 & immeasurable & stream, grain unbroken \\
3 & immeasurable & stream, whole grains \\
4 & immeasurable & stream, whole grains \\
No. & Time to slide off the cascade (s) & Comments \\
1 & 3.64 & stream, grain unbroken \\
2 & 3.54 & stream, grain unbroken \\
3 & 3.73 & stream, grain unbroken \\
4 & 3.86 & stream, grain unbroken \\
5 & 3.76 & stream, grain unbroken \\
6 & 3.74 & stream, whole grains \\
7 & 3.72 & stream, whole grains \\
8 & 3.68 & stream, whole grains \\
9 & 3.85 & stream, whole grains \\
10 & 3.76 & stream, whole grains \\
11 & 3.56 & sample, mass $1000 \mathrm{~g}$ \\
12 & 3.90 & sample, mass 1000 g \\
13 & 3.81 & sample, mass $1000 \mathrm{~g}$ \\
14 & 3.55 & sample, mass 1000 g \\
15 & 3.64 & sample, mass $1000 \mathrm{~g}$ \\
\hline
\end{tabular}

The length of the path on which the grain slides was calculated based on the structure of the cascade chute. The approximation of the calculation is based on the fact that the grain does not move horizontally along its entire path. The individual planes of the cascade chute arranged alternately at an angle of $38^{\circ}$ to the vertical are located at a distance from each other. The grain that moves from one plane to the next and changes direction during this time travels part of the way in the air. For the calculations, it was assumed that the grain that moves from one edge of the cascade chute to the other bounces on the surface. The calculated path of grain sliding in the column of the cascade chute from the height of $6.1 \mathrm{~m}$ is about $8.1 \mathrm{~m}$. Given the above, the velocity of grain movement on the surfaces of the cascade chute is approximately $\mathrm{v}=8.1 / 3.7=2.2\left(\mathrm{~m} \cdot \mathrm{s}^{-1}\right)$. This corresponds to the velocity of the grain moving vertically (to the bottom) $\mathrm{v}^{\prime}=1.6 \mathrm{~m} \cdot \mathrm{s}^{-1}$.

Finally, the result of the operation series of tests on the velocity of grain freely sliding down the cascade chute with respect to the free-fall velocity of the maize grain used as test material in Table 9 shows that the 6-metre cascade chute significantly slows the velocity of the grain falling during the loading of the silo.

\section{Conclusions}

The tests and the analysis of the results of research under simulated operating conditions aimed at checking the degree of damage to maize grain as a result of the application of the cascade chute compared to the control series. On the basis of the research, significant differ- 
Research on quality...

ences were demonstrated between the results in both series and the differences are not statistically significant. Four and five times less damage to maize grain was achieved as a result of the application of the cascade chute. In addition, the rate of fall of the grain during the loading of the silo was reduced, resulting in a slower slide of the grain and, thereby, limiting the proportion of grains damaged in the test.

Therefore, the innovative system for storing maize grain enables it to be used in full practical terms. This will improve the quality of maize grain and enable it to be stored safely in the silo.

\section{Acknowledgements}

The objective of this study is to disseminate the results of industrial research of the project entitled: "Research and development of an innovative, environmentally friendly system for drying and storing maize grains." The aforesaid research was supported by the National Centre for Research and Development and was carried out by the company POLNET sp. z o.o. i Wspólnicy Spółka Komandytowa, under agreement No POIG.01.04.00-30-237/13, as a project co-financed by the European Regional Development Fund, under the Operational Programme Innovative Economy 2007-2013, Measure 1.4 "Support for targeted projects."

\section{References}

Abass, A.B., Ndunguru, G., Mamiro, P., Alenkhe, B., Mlingi, N., Bekunda, M. (2014). Post-harvest food losses in a maize-based farming system of semi-arid savannah area of Tanzania. Journal of Stored Products Research, 57, 49-57. https://doi.org/10.1016/j.jspr.2013.12.004

Bassu, S., Brisson, N., Durand, J.-L., Boote, K., Lizaso, J., Jones, J.W., Waha, K. (2014). How do various maize crop models vary in their responses to climate change factors? Global Change Biology, 20(7), 2301-2320. https://doi.org/10.1111/gcb.12520

Bbosa, D., Brumm, T.J., Bern, C.J., Rosentrater, K.A., Raman, D.R. (2017). Evaluation of hermetic maize storage in 208 liter barrels (55 GAL) Steel Barrels for Smallholder Farmers, Agricultural and Biosystems Engineering Publications, 60(3), 981-987.

Bernardes, T.F., Daniel, J.L.P., Adesogan, A.T., McAllister, T.A., Drouin, P., Nussio, L.G., Huhtanen, P., Tremblay, G.F., Bélanger, G., Cai, Y. (2018). Silage review: Unique challenges of silages made in hot and cold regions. Journal of Dairy Science, 101(5), 4001-4019. https://doi.org/10.3168 /jds.2017-13703

Carvalho, B.F., Ávila, C.L.S., Bernardes, T.F., Pereira, M.N., Santos, C., Schwan, R.F. (2017). Fermentation profile and identification of lactic acid bacteria and yeasts of rehydrated corn kernel silage. Journal of Applied Microbiology, 122(3), 589-600. https://doi.org/ 10.1111/jam.13371

Evenson, R.E., Gollin, D. (2015). Assessing the impact of the Green Revolution. Science, 300(5620), 758-762. https://doi.org/10.1126/science. 1078710

FAOSTAT. (2018). Statistical databases and data-sets of the Food and Agriculture Organizations of the United Nations. Retrieved July 27, 2018, from http://www.fao.org.

Giorni, P., Battilani, P., Pietri, A., Magan, N. (2008). Effect of aw and CO2 level on Aspergillus flavus growth and aflatoxin production in high moisture maize post-harvest. International Journal of Food Microbiology, 122(1-2), 109-113. https://doi.org/10.1016/J.IJFOODMICRO.2007.11.051

Herrmann, A., Rath, J. (2012). Biogas production from maize: Current state, challenges, and prospects. 1. Methane Yield Potential. Bioenergy Research, 5(4), 1027-1042. https://doi.org/10.1007/s12155012-9202-6 
Liu, S., Song, F., Liu, F., Zhu, X., Xu, H. (2012). Effect of planting density on root lodging resistance and its relationship to nodal root growth characteristics in maize (Zea mays L.). Journal of Agricultural Science, 4. https://doi.org/10.5539/jas.v4n12p182

Meyers, T.P., Hollinger, S.E. (2004). An assessment of storage terms in the surface energy balance of maize and soybean. Agricultural and Forest Meteorology, 125(1-2), 105-115.

https://doi.org/10.1016/j.agrformet.2004.03.001

Polish Central Statistical Office. (2005). Land use, sown area and livestock population.

Polish Central Statistical Office. (2018). Land use, sown area and livestock population.

Scaar, H., Franke, G., Weigler, F., Delele, M., Tsotsas, E., Mellmann, J. (2015). Experimental and numerical study of the airflow distribution during mixed-flow grain drying. Drying Technology, 4. https://doi.org/10.1080/07373937.2015.1064946

Shiferaw, B., Smale, M., Braun, H.J., Duveiller, E., Reynolds, M., Muricho, G. (2013). Crops that feed the world 10. Past successes and future challenges to the role played by wheat in global food security. Food Security, 5(3), 291-317. https://doi.org/10.1007/s12571-013-0263-y

Suleiman, R., Bern, C.J., Brumm, T.J., Rosentrater, K.A. (2018). Impact of moisture content and maize weevils on maize quality during hermetic and non-hermetic storage. Journal of Stored Products Research, 78, 1-10. https://doi.org/10.1016/j.jspr.2018.05.007

Tonui, K.S., Mutai, E.B.K., Mutuli, D.A., Mbuge, D.O., Too, K.V. (2014). Design and evaluation of solar grain dryer with a back-up heater. Research Journal of Applied Sciences, Engineering and Technology, 7(15), 3036-3043. https://doi.org/10.19026/rjaset.7.639

Walker, S., Jaime, R., Kagot, V., Probst, C. (2018). Comparative effects of hermetic and traditional storage devices on maize grain: Mycotoxin development, insect infestation and grain quality. Journal of Stored Products Research, 77, 34-44. https://doi.org/10.1016/j.jspr.2018.02.002

Weigler, F., Scaar, H., Mellmann, J. (2012). Investigation of particle and air flows in a mixed-flow dryer. Drying Technology, 30(15), 1730-1741. https://doi.org/10.1080/07373937.2012.703742

Zhu, F. (2018). Effect of ozone treatment on the quality of grain products. Food Chemistry, 264(May), 358-366. https://doi.org/10.1016/j.foodchem.2018.05.047

\section{BADANIE JAKOŚCI ZIARNA KUKURYDZY W WYNIKU ZASTOSOWANIA INNOWACYJNEGO SYSTEMU SKLADOWANIA ZIARNA W WARUNKACH OPERACYJNYCH}

Streszczenie. W artykule przedstawiono wyniki badań w zakresie poprawy jakości ziarna dzięki zastosowaniu rdzenia zasypowego w silosie zbożowym. Badania wykonano w ramach projektu badawczego, którego celem było stworzenie innowacyjnego systemu składowania ziarna kukurydzy m.in. ograniczającemu uszkodzeniu ziarna. Wykonane zostały dwie serie: kontrolna, w której jako główny element zastosowano zrzutnię oraz seria eksploatacyjna, w której do badań zastosowano kaskadę zasypową. Analiza w symulowanych warunkach operacyjnych wykazała 4-5-krotnie zmniejszenie ziaren uszkodzonych po zastosowaniu rdzenia zsypowego w porównaniu do serii kontrolnej. Wykazano także, że 6-metrowa kaskada zasypowa spowalnia w znacznym stopniu prędkość spadania ziarna podczas załadunku silosu.

Słowa kluczowe: kukurydza, silos, jakość ziarna 